\title{
ПОНЯТИЕ «КОРЕННОЙ НАРОД» И ИХ СТАТУС В МЕЖДУНАРОДНОМ И ВНУТРИГОСУДАРСТВЕННОМ ПРАВЕ
}

\begin{abstract}
Аннотация. В статье содержит подробный анализ всех имеющихся на сегодняшний день в международном праве определений понятия «коренной народ». Автором подробно анализируются основные признаки коренных народов, приводимые в трудах отечественных и зарубежных ученых. Автор также обращается к внутреннему законодательству США, Канады и России в части определения коренных народов этих стран и соотносит их с национальными меньшинствами.

Ключевые слова: Юриспрудениия, Коренные народы / Indigenous Peoples, Коренные малочисленные народы России / Indigenous, Аборигены / Aborigines, Автохтонное население / Autochthonic Population, Индейиы / American Indians, Исконные народы, Национальные меньиинства, First Nations, National Minorities

Review: The article contains detailed analysis of all existing conceptual definitions of «indigenous people», as available today in international law. The article includes detailed analysis of the basic attributes of indigenous peoples according to the works of Russian and foreign scientists. The author also turns to the domestic legislation of the USA, Canada and Russia regarding definitions of indigenous peoples in these states and their correlation with national minorities.

Keywords: jurisprudence, indigenous peoples, indigenous small-numbered people of Russia, aboriginal, indigenous, autochthonic population, American Indians, fist nations, national minorities.
\end{abstract}

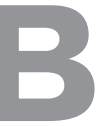

свое время французский мыслитель Рене Декарт писал: «Дайте понятиям точное толкование, и вы освободите мир от половины заблуждений». ${ }^{1}$ Так, например, такие термины, как «народ», «нация», «коренной народ» не имеют в юридической литературе однозначной трактовки. Для того чтобы найти ответы на эти вопросы необходимо обратиться к международным документам и трудам юристов международников.

Народ впервые стал общепризнанным субъектом международного права в 1945 году в результате закрепления в Уставе $\mathrm{OOH}$ принципа «равноправия и самоопределения народов». Будучи базовым, право народов на равенство и самоопределение дало толчок становлению и развитию других прав народов (наций). ${ }^{2}$ Вместе

\footnotetext{
${ }^{1}$ См.: История политических и правовых учений / Под. Ред. проф. Нерсесянца В.С. - М.: Норма, 2001. - С.54.

${ }^{2}$ См.: Международное публичное право. Курс лекций. / Отв. ред. проф. Курдюков Г.И. - Казань: Издательство «Центр инновационных технологий», 2004. - С.108.
}

с тем общепринятого всем международным сообществом понятия «народ» до сих пор нет. Не только в международно-правовой, но и в этнографической литературе дискуссии на эту тему идут с XIX века.

В юридической литературе приводится классификация народов с учетом истории и условий их развития по типам (этносам), категориям и расам. По этносам или типам: племя, народность и нация. По категориям или группам: коренные (государствообразующие или малочисленные), национальные меньшинства, колониальные, разделенные. По расам: черная, желтая и белая. ${ }^{3}$ Выделяют также еще и красную расу, куда относят коренное население Америки индейцев, хотя цвет их кожи варьируется в зависимости от региона проживания.

\footnotetext{
${ }^{3}$ См.: Права человека и народов. Учебное пособие / Под ред. проф. Миронова О.О. - Москва-Саратов: Издат. Центр ИНСР; Саратовский юридический институт МВД России. 2006. - C.211.
} 
Понятие «коренной народ»является понятием международного права. Коренные народы представляют различные этносы, расы, религии и ведут различный образ жизни в самых разных уголках нашей планеты. В Европе это: саами, проживающие в Финляндии, Швеции, Гренландии, Норвегии и России; баски в Испании, Франции и Португалии. В Азии: различные племена в Индии, Китае, Пакистане; народ айна в Японии; ${ }^{4}$ народности Сибири, Севера и Дальнего Востока России. В Африке: берберы, бушмены и многие другие народы. Американские континенты населяют индейцы, алеуты и иннуиты (эскимосы). В Австралии и Новой Зеландии проживают аборигены и народ маори.

Достаточно трудно подвести всех их под какое-нибудь одно официальное определение, которое являлось бы нарицательным именем для всех аборигенов, хотя у них и есть много общего, что можно использовать для доктринального и конвенционного определения понятия «коренной народ». В связи с этим в доктрине международного права постоянно продолжается активная работа над определением понятия «коренные народы». Как правило, при решении вопроса об их определении исследователи сходятся в том, что в основу разработки должен быть заложен подход, направленный на всеобъемлющий охват коренных народов, который включал бы все типологическое и видовое разнообразие этих групп и в то же время базировался на каких-то общих критериях. Такие критерии, несмотря на то, что некоторые из них вызывают споры, уже выработаны в теории и практике международного права.

Во-первых, они являются потомками тех людей и народов, которые заселяли данную территорию до прихода людей и народов с другой культурой, религией, языком, обычаями другого этнического и расового происхождения. Как отмечает известный американский профессор Джеймс Анайя, коренные народы, в широком смысле,

\footnotetext{
${ }^{4}$ Правительство Японии официально признали народ айна, проживающий на севере страны коренным народом только в июне 2008 года. Был подтвержден тот факт, что этот народ имеет собственный язык, религию и культуру и Япония не является гомогенным в этническом плане государством.
}

являются потомками людей, населявших данную территорию до прихода других народов. ${ }^{5}$ Таким образом, это относительное понятие, т.е. можно быть коренным относительно какого-то другого народа. Так, например, Североамериканские индейцы являются коренными народами относительно английских, испанских, французских и иных колонистов, завезенных африканских рабов и т.д. В широком смысле слова все люди являются коренными в той или иной местности относительно других людей (пришлых).

Во-вторых, по мнению Ананидзе Ф.Р., на общегосударственном уровне они занимают недоминирующее, в подавляющем большинстве - зависимое, а порой и дискриминационное положение. ${ }^{6}$ Такого же мнения придерживаются Блищенко И. и Абашидзе А.Х. ${ }^{7}$ Однако здесь следует не согласиться с позицией авторов, так как это является не признаком коренного народа, а следствием несправедливой государственной политики по отношению к ним. К тому же в ряде государств коренное население составляет большинство по отношению к некоренным нациям (страны Южной Америки) и в некоторых из них государственная политика меняется на глазах в лучшую сторону (например, Боливия, где была принята новая конституция). ${ }^{8}$

В-третьих, они характеризуются культурными, языковыми, традиционными, часто расовыми отличиями от остальной части населения данной страны или региона, а иногда даже и целого континента (например, Австралия).

В-четвертых, они сознательно считают себя таковыми (коренными) и такое самосознание является частью их культуры, религии, бытия и существования. Со стороны представляется несложным отличить коренных жителей по их одежде, языку, обычаям и другим культурным особенностям. Однако принадлежность к корен-

\footnotetext{
${ }^{5}$ Cм.: James S. Anaya. Indigenous Peoples in International Law. Second Edition. - Oxford University Press, 2004. - P.3.

${ }^{6}$ См.: Ананидзе Ф.Р. Международно-правовые проблемы защиты прав коренных народов. - Дисс. ... на соискание ученой степени канд. юрид. наук. - Москва. - 1996. - С.13.

${ }^{7}$ См.: Блищенко И., Абашидзе А.Х. Коренные народы и международное право // Российская юстиция. - № 3. - 1994. - С.24.

${ }^{8}$ В Боливии впервые президентом страны был избран представитель коренного народа (Эво Моралез принадлежит к народности аймара, потомкам империи инков).
} 
ному народу не сводится только лишь к наличию каких-либо внешних признаков. Она выражается в чувстве духовной близости, сознания принадлежности к самобытной культуре, обладающей характерными особенностями. Коренной народ считает, что он отличается от основных слоев общества в современном обществе. Сознание принадлежности к коренному населению объединяет народы совершенно разных культур - от индейцев навахо в Северной Америке до чукчей на российском Севере.

И, последнее, они привязаны к родной земле, природе и окружающей их среде, что выражается во взаимосвязи и взаимозависимости этих двух понятий (коренной народ - земля). Для многих аборигенов земля считается одухотворенной и всякая деятельность, связанная с добычей полезных ископаемых может причинить ей боль. Владение землей или отношение к ней как к товару, который может быть использован, считается у них преступлением. Словом, коренной народ без родной земли - это уже не коренной народ. ${ }^{9}$ Данное обстоятельство является главной отличительной чертой коренных народов от национальных меньшинств.

При любой попытке принять правовое определение, которое могло бы получить всеобщее признание, несомненно, следует в полной мере учитывать точки зрения самого коренного народа, а не только мнение правительств, то есть должны учитываться мнения как одной, так и другой стороны с целью избегания злоупотребления своими правами или полномочиями как со стороны правительств, так и со стороны коренных народов.

Согласно данным Организации Объединенных Наций в мире насчитывается около 300 - 350 млн. представителей коренных народов, проживающих в 72 странах. Примерно $70 \%$ из них приходится на государства Азии, в частности Индия, Иран, Ирак. В то же время ученые Африки и Азии не приемлют сложившееся в западной доктрине определение понятия «коренной народ» и предлагают ограничить его действие Австралией и

\footnotetext{
${ }^{9}$ См.: Абашидзе А.Х., Ананидзе Ф.Р. Правовой статус меньшинств и коренных народов: международно-правовой анализ. Монография. - М.: Издательство РУДН, 1997. - С.46.
}

Америкой. ${ }^{10}$ В частности Бангладеш и Индия заявили, что не могут определить, кто является более коренным среди народов, населяющих эти страны. ${ }^{11}$ В Азии европейская оккупация явилась лишь последним звеном в цепи колониальных завоеваний, туда переселилось небольшое количество иностранцев, и вопрос о принадлежности к коренным народам носит достаточно сложный характер. Так, например, постоянный приток народов на Индийский субконтинент в течение последней тысячи лет сделал практически неразрешимым вопрос о том, кто первый появился на его территории.

В Африке, как и в Азии, понятие коренной народ применяется к тем народам, которым угрожает опасность и которые не являются доминирующими. Это, например, народы сан (бушмены) в пустыне Калахари и мбати (пигмеи) во влажных тропических лесах Центральной Африки, традиционный образ жизни которых все больше подвергается отрицательным воздействиям со стороны поселенцев. Большинство африканских государств, в частности, тропическая экваториальная Африка, вообще этой концепции не признают и считают, что все народы являются коренными.

Что же касается регионов, где имело место крупномасштабное переселение европейцев, выявить коренные народы сравнительно просто. Это в основном Американский континент, Австралия, Новая Зеландия, север Европы, Сибирь и российский Дальний Восток. Идея о том, что первоначальное занятие территории дает коренным народам определенные права и требования, не относящиеся к иным меньшинствам, достаточно хороша для Америки и Австралии, где специфическая история завоевания и этническая отчетливость, сделали этот аргумент относительно легким для развития. Они разделяют несправедливое прошлое по отношению к ним. Их убивали, пытали и порабощали. Очень часто они были жертвами геноцида. Их лишали права участия в процессе управления в современных государственных структурах. Завоевание и коло-

\footnotetext{
${ }^{10}$ CM.: John R. Bowen. Should We Have a Universal Concept of «Indigenous Peoples' Rights»?: Ethnicity and Essentialism in the Twenty-First Century // Anthropology Today. - Vol. 16. - № 4. - 2000. - P.13.

${ }^{11}$ См.: Lee Swepston. Indigenous and Tribal Peoples and International Law: Recent Developments // Current Anthropology. - Vol. 30. - № 2. - 1989. - P.260.
} 
низация коренных народов имело целью лишить достоинства и этнической особенности, свойственных коренным народам, а также фундаментального права на самоопределение.

В международной терминологии, построенной на греческих и латинских основах используются следующие определения относительно коренного народа - это: аборигенное, автохтонное, индигенное население. Термин «автохтоны», образованный от древнегреческих основ «сам» и «земля», иными словами «Самоземцы» определяет уроженцев определенной местности. Латинское выражение «indigenos» является калькой термина «автохтон» и тоже обозначает уроженцев определенной местности. ${ }^{12} \mathrm{~B}$ литературе можно также встретить такую терминологию, как «исконные народы», «первоначальные», «четвертый мир».

В отечественной литературе для обозначения коренных народов встречаются также такие термины, как «туземцы» и «инородцы», которые характерны именно для России и использовались уже на самом раннем этапе освоения Сибири и Севера. Туземцы - это население «тех земель». В словаре В.И. Даля этот термин определяется как «здешний, тамошний уроженец, природный житель страны, о коей речь». ${ }^{13}$ Схожими понятиями являются «иноземец» и «чужеземец», за исключением лишь того, что они рассматривались как пришлые люди, в то время как туземцы это население собственной страны.

Еще один термин - это «аборигены», который берет свое начало от латинского «аb origene». Так английские завоеватели назвали коренных жителей Австралии. История Австралии не знает ни договоров, ни признания прав коренного населения, а в начале XIX века проводились даже серьезные юридические дебаты по вопросу о том, являются ли коренные австралийцы действительно людьми в такой степени, что их убийство можно считать уголовным преступлением. ${ }^{14}$ Политика неприз-

\footnotetext{
${ }^{12}$ См.: Соколовский С.В. Категория «коренные народы» в российской политике, законодательстве и науке // Kennan Occasional Papers. - Washington, 1999.

${ }^{13}$ См.: Даль В. И. Толковый словарь живого великорусского языка. - М., 1994. - Т.4. - С.441.

${ }^{14}$ См.: Морс Б. Сравнительная оценка положения коренных народов в Канаде, США, Австралии и Новой Зеландии // Человек и право: Книга о Летней школе по юридической антропологии. - М.: Стратегия, 1999. - С.64.
}

нания прав коренного населения продолжалась в Австралии вплоть до 1967 года, когда на них было распространено избирательное право, после чего начался процесс признания и других прав.

Понятие «коренной народ» всегда определялось, называлось, и толковалось по-разному. В международно-правовой литературе оно впервые появилось в 1921 году в связи с проведением Международной организаций труда исследования по проблемам трудящихся из числа коренного населения. Затем уже оно нашло свое отражение в Конвенции МОТ № 501936 года «О регламентации некоторых особых систем вербовки трудящихся», Конвенции МОТ № 641939 года «О трудовых договорах трудящихся коренного населения», Конвенции МОТ № 841947 года «О трудовых договорах трудящихся коренного населения». Согласно этим документам под коренными народами подразумевалось в основном местное население, аборигены колониальных владений «цивилизованных государств»..$^{15}$ До принятия в 1957 году Конвенции МОТ № 107 «О защите и интеграции коренного и другого населения, ведущего племенной и полуплеменной образ жизни, в независимых странах» термин «коренные народы» в международно-правовых документах присутствовал, но отсутствовало само определение данного понятия, поэтому он толковался по-разному и зачастую получал различную интерпретацию.

Несмотря на отсутствие общепринятого определения коренного народа, отправной точкой считается рабочее определение $\mathrm{OOH}$, сформулированное Специальным докладчиком по проблеме дискриминации коренного населения для Подкомиссии ООН по предупреждению дискриминации и защите меньшинств Хосе Мартинесом Кобо. Согласно его определению «коренной народ состоит из нынешних потомков народов, которые проживали на нынешней территории всей или части какой-либо страны в момент, когда на нее прибыли из других частей мира лица другой культуры и этнического происхождения, которые покорили их и поставили в зависимое и колониальное положение путем завоевания, коло-

\footnotetext{
15 См.: МОТ - конвенции и рекомендации, принятые Международной конференцией труда, 1919-1966. - Женева: Международное Бюро Труда, 1983. - С.381.
} 
низации и других средств; в настоящее время эти народы живут более в соответствии с их особыми обычаями и социальными, экономическими и культурными традициями, чем с институтами страны, частью которой они являются, при государственной структуре, которая основывается главным образом на национальных, социальных и культурных особенностях других господствующих слоев населения». ${ }^{16}$ Необходимо отметить, что Рабочая группа ООН по правам коренных народов, Подкомиссия ООН по предупреждению дискриминации и защите меньшинств, а также Комиссия ООН по правам человека признали данное определение коренных народов в качестве основы для будущей работы по проблемам коренного населения. ${ }^{17}$

В своем окончательном докладе в 1982 году Специальный докладчик предложил альтернативную формулировку своего первоначального рабочего определения: «Коренной народ - это коренные общины, народности и нации, сохраняющие историческую преемственность с обществами, которые существовали до вторжения завоевателей и введения колониальной системы и развивались на своих собственных территориях, считающие себя отличающимися от других слоев общества, преобладающих в настоящее время на этих территориях или на части этих территорий. Они составляют слои общества, не являющиеся доминирующими, и хотят сохранить, развивать и передать будущим поколениям территорию своих предков и свою этническую самобытность в качестве основы для продолжения своего существования как народа в соответствии со своими собственными культурными особенностями, социальными институтами и правовыми системами. ${ }^{18}$ То есть в новом определении нововведением явилось то, что право определять, кто является «коренным», принадлежит самому коренному народу. Соответствующая группа может принимать решение о включении или исключении определенных лиц.

\footnotetext{
${ }^{16}$ См.: Организация Объединенных Наций, документ Е/CN.4/ Sub.2/L/566 от 29 июня 1972 года.

${ }^{17}$ См.: Новикова Н.И. Права человека и права коренных народов Севера России // Человек и право. - М., 1999. - С. 55.

${ }^{18}$ См.: Организация Объединенных Наций, документ Е/CN.4/ Sub.2/1986/7 add.4, пункт 379.
}

Стоит заметить, что данное право коренного народа нашло свое отражение и утверждение в Декларации принципов коренных народов, которая была разработана и принята на Всемирной конференции по коренным народам в Панаме в сентябре 1984 года, принцип пятый которой гласит: «Все коренные народности имеют право определять, какие лица или группы лиц включаются в их состав». ${ }^{19}$ В тоже время в определении нет указания на право коренных народов на самоопределение, что вряд ли оправдано. Спорным также является признание коренными народами при прочих условиях лишь те народы, территория которых подверглась вторжению завоевателей и введению колониальной системы. Получается, что, например, такие европейские народы, как курды или баски не будут подпадать под понятие коренных народов, и их следует отнести к иным группам меньшинств (национальным, языковым, религиозным). В то же время народы, занимающиеся охотой, рыболовством, оленеводством и другими видами традиционных промыслов за Северным полярным кругом (саамы, чукчи, эскимосы и т.д.) - считаются коренными, что признается международным сообществом в целом и находит свое отражение в нормах международного права и подтверждается практикой международных организаций. ${ }^{20}$

Дальнейшее упрочение позиций этого понятия в международном праве произошло после пересмотра Конвенции 1957 года, когда в новой Конвенции № 169, принятой в 1989 году, речь уже шла о «коренных народах». Специальный комитет, который рассматривал проект Конвенции № 169, при обсуждении последнего варианта статьи 1, где речь идет о понятии «коренные народы», перед собой имел 19 поправок, поступивших от

\footnotetext{
${ }^{19}$ См.: James Crawford. The Rights of Peoples. - Oxford: Clarendon Press, 1988. - P.205.

${ }^{20}$ См.: Пешперова И.Ю. Гарантии прав коренных малочисленных народов с международном и внутригосударственном праве // Права коренных народов Севера: реализация международно-правовых стандартов в Российской Федерации: Сборник научных статей / Под ред. акад. РАО Г.А. Бордовского, проф. С.А. Гончарова. - СПб.: Издательство РГПУ им. А.И. Герцена, 2005. - С.73.
} 
различных правительств и организаций, в которых предлагались разные названия. ${ }^{21}$

Согласност.1 Конвенции№ 169 онараспространяется:

a) на народы, ведущие племенной образ жизни в независимых странах, социальные, культурные и экономические условия которых отличают их от других групп национального сообщества и положение которых регулируется полностью или частично их собственными обычаями или традициями, или специальным законодательством;

b) на народы в независимых странах, которые рассматриваются как коренные ввиду того, что они являются потомками тех, кто населял страну или географическую область, частью которой является данная страна, в период ее завоевания или колонизации или в период установления существующих государственных границ, и которые, независимо от их правового положения, сохраняют некоторые или все свои социальные, экономические, культурные и политические институты.

По мнению Андреева К.Ю. данное определение свидетельствует о том, что МОТ стремилась защитить не все коренные народы, а наиболее уязвимые перед лицом цивилизации, исходила из того, что необходимо обеспечить в первую очередь защиту тем коренным народам, которые ведут традиционный образ жизни и именно с ним связаны их идентичность и язык. ${ }^{22}$ Обе конвенции выделяют еще и такую категорию населения, как народы, ведущие племенной образ жизни. В мире насчитывается около 50 миллионов человек, которые относятся к этой категории. ${ }^{23}$ К тому же племенной образ жизни могут вести не обязательно лица, принадлежащие к коренному населению данной территории. МОТ рассматривает эти категории народов раздельно, такой подход был заложен

\footnotetext{
${ }^{21}$ См.: Абашидзе А.Х., Ананидзе Ф.Р. Правовой статус меньшинств и коренных народов: международно-правовой анализ. Монография. - М.: Издательство РУДН, 1997. - С.39.

${ }^{22}$ См.: Андреев К.Ю. Правовой статус коренных малочисленных народов в зарубежных странах. Справочник. - М.: РАН ИНИОН, 2006. - С.10.

${ }^{23}$ См.: Ли Свепстон. Конвенция Международной организации труда «О коренных народах и народах, ведущих племенной образ жизни, в независимых странах»: международный опыт ратификации и применения, проблемы и перспективы // Материалы Круглого Стола «О ратификации Российской Федерацией Конвенции МОТ № 169 «О коренных народах и народах, ведущих племенной образ жизни, в независимых странах». - М.: Общественная палата, 2006. - С.24.
}

в самом начале рассмотрения этих документов. Таким образом, под защиту берется не столько коренное население, сколько традиционный образ жизни, являющийся источником их пропитания.

Помимо этих определений к толкованию термина «коренные народы» обращался Всемирный банк в двух своих документах - Оперативная директива Всемирного банка 4.20 и Операционная политика Всемирного банка 4.10. В международных документах применяется также термин «Native», означающий уроженца данной местности или туземца. Так, например, индейцев в США называют «Native Americans». А в Австралии понятием «Native» обозначают белых жителей страны, родившихся в Австралии в отличии от приехавших. ${ }^{24}$

По определению Министерства внутренних дел США, к индейцам обычно причисляют человека, который отвечает как минимум двум критериям этнического и социального характера. Во-первых, в его жилах, хотя бы отчасти, течет индейская кровь. Во-вторых, он должен быть признан индейцем или членом племени одним из признанных США племен и (или) правительством США. Однако, критерии причисления к индейцам различаются не только на федеральном и племенном уровнях, но и внутри них. Правительственные агентства используют различные показатели для определения права того или иного человека на участие в программах и на получение услуг. В разных племенах также существуют свои подходы к включению в число членов племени.

В Канаде по отношению к индейцам применяется термин «First Nations», что означает «Первые нации». Нормы об отдельных элементах статуса коренных народов были включены еще в Конституционный акт Канады 1867 года, формальное же признание прав аборигенного населения Канады произошло еще раньше - в Королевской декларации 1763 года. Общественные отношения, связанные с коренными народами, считаются настолько важными, что в Конституционном акте 1982 года им посвящена специальная часть под названием «Права коренных народов Канады». Содержащиеся в ней статьи со-

\footnotetext{
${ }^{24}$ См.: Ткаченко A.А., Корюхина А.В. К проблеме ратификации Российской Федерацией Конвенции МОТ № 169 «О коренных народах и народах, ведущих племенной образ жизни в независимых странах». // Этнографическое обозрение. - № 3. - 1995. - С.125.
} 
здают систему гарантий в отношении договоров с коренными народами, принципа равноправия мужчины и женщины, содержат определение понятия «коренные народы», положения о регулировании земельных отношений. ${ }^{25}$

В канадском Конституционном акте 1982 годы говорится, что под термином коренное население Канады понимаются индейцы, иннуиты и метисы Канады. Согласно переписи населения 2001 года сообщается, что 1,3 млн. людей считают себя коренными жителями, из них 976305 назвали себя североамериканскими индейцами, 292310 метисы и 45070 - иннуиты. Все они составляют $4 \%$ от общего населения Канады. ${ }^{26}$ Таким образом из этих трех категорий больше всего индейцев, которые в свою очередь подразделяются на зарегистрированных в качестве принадлежащих к коренному народу (статусные индейцы) и на не зарегистрированных в таком качестве (не статусные индейцы). Первые обладают рядом льгот и дополнительных прав, вторые нет.

Практически все племена Канады имеют свои конституции. Согласно статье 10 Акта о самоуправлении коренных народов Юкона 1994 года: «каждый коренной народ должен хранить в главном административном учреждении перечень законов, включая конституцию данного народа и все законы, принятые данным народом, с тем, чтобы любое лицо могло иметь доступ к законам данного народа в рабочее время». ${ }^{27}$ Договоры, заключенные в прошлом коренными народами, в современной Канаде рассматриваются как важная гарантия прав коренных народов. Они получили защиту в Конституционном акте 1982 года, где статья 35(1) гласит: «Существующие исконные или вытекающие из договоров права коренных на-

${ }^{25}$ См.: Андреев К.Ю. Правовой статус коренных малочисленных народов в зарубежных странах. Справочник. - М.: РАН ИНИОН, 2006. - С.46.

${ }^{26}$ См.: Bradford $W$. Morse. Participatory in Public and Aboriginal Governments in Northen Canada // Актуальные вопросы прав народов в современном мире. Материалы международной научно-практической конференции / Отв. ред. Гарипов Р.Ш. - Казань: Издательство Татарского государственного гуманитарно-педагогического университета, 2009. - С.35.

${ }^{27}$ См.: Коренные народы Канады, нефть и закон: Сборник законодательных актов территории Юкон / Под ред. Солдаткина Е.И. и др. - М.: Ассоциация коренных малочисленных народов Севера, Сибири и Дальнего Востока Российской Федерации, 2002. - С.52. родов Канады признаются и подтверждаются». ${ }^{28}$ Таким образом, обязательства перед коренными народами возводятся на конституционный уровень, что обеспечивает им повышенную защиту и гарантии со стороны государства.

У нас, в России, используется термин «коренные малочисленные народы» или просто «малочисленные народы», который включает в себя 45 наименований малочисленных народов ${ }^{29}$ проживающих на территориях традиционного расселения своих предков, сохраняющие традиционные образ жизни, хозяйствование и промыслы, насчитывающие в Российской Федерации менее 50 тысяч человек и осознающие себя самостоятельными этническими общностями. ${ }^{30}$ Таким образом, с точки зрения юридической нормы лишь некоторая часть народов России может именоваться коренными народами (с учетом численного критерия).

По мнению профессора Кряжкова В.А., коренные малочисленные народы - это разновидность коренных народов и особая группа национальных меньшинств. ${ }^{31}$ В Конституции РФ используются два термина - «коренные малочисленные народы» и «малочисленные этнические общности», которые в значительной степени компенсируют друг друга. Наряду с этим в федеральных актах употребляются понятия «малочисленные народы», «коренные (аборигенные) народы», «коренные малочисленные народы Севера, Сибири и Дальнего Востока». В конституциях и уставах субъектов федерации употребляются такие термины, как «малочисленные этнические группы», «коренные народы» и «малочисленные народы Севера». Перенесение в законодательство различных терминов, употребляемых в научном обороте, и параллельное их использование еще более затрудняет выявление

\footnotetext{
${ }^{28}$ См.: Андреев К.Ю. Правовой статус коренных малочисленных народов в зарубежных странах. Справочник. - М.: РАН ИНИОН, 2006. - С.55.

${ }^{29}$ См.: Постановление Правительства РФ от 24.04.2000 года № 255 «О Едином перечне коренных малочисленных народов Российской Федерации»

${ }^{30}$ См.: Федеральный закон от 30.04.1999 года № 82-Ф3 «О гарантиях прав коренных малочисленных народов Российской Федерации» // СЗ РФ. - 1999. - № 18. - Ст.2208.

${ }^{31}$ См.: Кряжков В.A. Право на родной язык: на примере малочисленных народов Севера // Российский юридический журнал. - 2007. - № 1. - С.23.
} 
объектов охраны права и отрицательно влияет на эффективность реализации правовых норм.

Проблема прав коренных малочисленных народов длительное время рассматривалась только как часть более общей проблемы правового положения национальных меньшинств, часть которых составляют и коренные народы. Поскольку коренные народы практически повсеместно являются национальными меньшинствами, все международные и внутригосударственные правовые нормы, относящиеся к национальным меньшинствам, в то же время относятся и к коренным народам.

Многие коренные народы относятся к категории национальных меньшинств, например, в таких государствах как США, Россия, Австралия. Это обстоятельство дает им право использовать международные нормы о национальных меньшинствах, такие как: Декларация ООН о правах лиц, принадлежащих к национальным или этническим, религиозным и языковым меньшинствам 1992 года, Конвенция СНГ об обеспечении прав лиц, принадлежащих к национальным меньшинствам 1994 года, Рамочная конвенция Совета Европы о защите национальных меньшинств 1995 года и др. Статья 27 Международного о гражданских и политических правах определяет, что этническим, религиозным и языковым меньшинствам не может быть отказано в праве совместно с другими членами той же группы пользоваться своей культурой, исповедовать свою религию и исполнять ее обряды, а также пользоваться родным языком. ${ }^{32}$

Однако в некоторых странах Южной Америки коренные народы представляют большую часть населения (например, в Перу к коренным народам относятся около $45 \%$ населения, это потомки цивилизации инков - кечуа и аймара; в Боливии - $60 \%$ населения составляют народы кечуа, аймара и гуарани). К тому же на семинаре ООН по воздействию расизма и расовой дискриминации на социальные и экономические отношения между коренными народами и государствами, проходившем в Женеве 16-20 января 1989 года, было отмечено, что коренные народы не являются расовыми, этническими, религиозными и языковыми меньшинствами. С

\footnotetext{
${ }^{32}$ См.: Международный пакт о гражданских и политических правах 1966 года // Международные акты о правах человека. Сборник документов. Издание второе, дополненное / Сост. Карташкин В.А., Лукашева Е.А. - М.: НОРМА.-2002. - С.60.
}

таким категорическим утверждением не согласны отечественные ученые. ${ }^{33}$

По мнению ряда отечественных и зарубежных авторов, коренные народы (в том числе и малочисленные) представляют собой разновидность национальных меньшинств, поскольку обладают всеми признаками последних: своеобразием этнических характеристик по отношению к другой части населения страны; недоминирующей численностью и негосподствующим положением в государстве или регионе проживания, а также стремлением сохранить свою самобытность. ${ }^{34}$ К тому же, как подчеркивается в докладе для Независимой комиссии по международным гуманитарным вопросам, коренные народы даже в тех случаях, когда они составляют большинство в стране, обладают всеми характерными особенностями национальных меньшинств. Они имеют иной язык, религию, культуру, которые зачастую подвергаются дискриминации со стороны доминирующего населения. ${ }^{35}$ Примером могут служить ряд Южноамериканских государств.

Однако коренным народам присущи и свои специфические черты. В первую очередь - это наличие у них собственной территории. Во-вторых, меньшинства могут проживать некомпактно в среде доминирующей части населения страны, а коренные народы - это целостные этнические общности с признаком уникальности, имеющие свою собственную сферу обитания. В-третьих, в основе образа жизни и способа хозяйствования коренных народов на земле, которую населяли еще их предки, лежит традиционность. В-четвертых, отличие правового статуса коренных народов от правового статуса иных групп национальных меньшинств наиболее ярко прояв-

\footnotetext{
${ }^{33}$ См.: Абашидзе А.Х., Ананидзе Ф.Р. Правовой статус меньшинств и коренных народов: международно-правовой анализ. Монография. - М.: Издательство РУДН, 1997. - С.4.

${ }^{34}$ См.: Пунжин C.M. Проблема защиты прав меньшинств в международном праве // Государство и право. - № 8. - 1992. - С.123; Пешперова И.Ю. Международно-правовая регламентация прав коренных народов // Правоведение. - № 1. 1998. - C.187; Thornberry P. International Law and the Rights of Minorities. - Oxford, 1991. - P.331; Hannum H. Autonomy Sovereignty and Self-determination. - Philadelphia, 1990. - P. 74.

${ }^{35}$ См.: Коренное население: глобальное стремление к справедливости. Доклад для Независимой комиссии по международным гуманитарным вопросам. - М., 1990. - С.33.
} 
ляется, если рассмотреть их с точки зрения права на самоопределение. Коренной народ независимо от его численности обладает указанным правом, а другим группам национальных меньшинств право на самоопределение не предоставляется. ${ }^{36}$

Что касается национальных меньшинств, то они не обязательно должны быть представителями коренных народов и могут быть просто укоренившимися гражданами данного государства, отличающиеся от остального населения страны своей культурой, языком, религией и традициями. Их главное отличие от представителей коренных народов заключается в отсутствии у них исторической связи с территорией их настоящего проживания.

В России понятие «национальное меньшинство» появилось в документах советской России 1918-1920 гг. Декларация прав народов России, ставшая основой для политики молодого государства в отношении национальных меньшинств, закрепила принцип свободного развития национальных меньшинств и этнографических групп, населявших территорию России. ${ }^{37} \mathrm{~B}$ современной научной литературе дается следующее определение национальных меньшинств: это часть представителей данной нации, проживающая в инонациональной среде за пределами традиционного поселения, но продолжающая сохранять свою самобытность, язык и культуру. К национальным меньшинствам можно отнести следующие виды этнических общностей:

1. Общности, проживающие на территории России, но имеющие государственные образования за ее пределами, например, поляки.

2. Общности, проживающие на территории России и не имеющие своих государственных образований, как в составе Российской Федерации, так и за рубежом, например, цыгане.

3. Общности, проживающие за пределами своих национально-государственных и националь-

\footnotetext{
${ }^{36}$ См.: Пешперова И.Ю. Международно-правовая регламентация прав коренных народов // Правоведение. - № 1. - 1998. - C. 187

${ }^{37}$ См.: Васильева Л.Н. Регулирование прав национальных меньшинств и коренных малочисленных народов: опыт Российской Федерации // Журнал российского права. - № 6. - 2005. - С.155.
}

но-территориальных образований в составе Российской Федерации, например, карелы. ${ }^{38}$ Из этого следует, что под национальным меньшинством понимается этническая общность в составе государства, нуждающаяся в защите от возможных дискриминации и нарушения гражданских, политических и иных прав. В то же время, как пишет профессор Абашидзе А.Х., факт существования на территории государств меньшинств еще не означает, что в этой стране существует проблема меньшинств. ${ }^{39}$ Этнические, национальные, культурные и языковые отличия служат лишь основаниями самоотождествления себя в качестве в качестве национального, этнического или языкового меньшинства для групп людей, осуществляемого добровольно, на основе свободного волеизъявления соответствующих лиц в соответствии с принципом недискриминации и равноправия.

Коренные же народы постоянно стремятся к тому, чтобы их рассматривали не просто как еще одну разновидность национальных меньшинств, а как сообщества с особым статусом. Нормы, касающиеся защиты прав национальных меньшинств, не обеспечивают защиту ряда особенностей коренных народов, лежащих в основе их выделения как самостоятельных народов и раскрывающих специфику их самобытности. Речь идет о таких основополагающих отличиях этих народов, как их неразрывная, в том числе духовная, связь со своими исконными землями, территориями и природными ресурсами. Отсюда и их соответствующая зависимость от благополучия исконной среды обитания. В связи с этим правовые акты, направленные на защиту прав национальных меньшинств, хотя и способствуют обеспечению защиты прав коренных малочисленных наров, однако далеко ее не исчерпывают, так как не направлены на защиту отдельных важных особенностей самобытности коренных малочисленных народов. Поэтому требуется дополнительная защита их прав, как на международном, так и на государственном уровне.

\footnotetext{
${ }^{38}$ См.: Тэпс Д. Соотношение понятий национальных меньшинств и коренных малочисленных народов // История государства и права. - 2006. - № 1. - С.7.

${ }^{39}$ См.: Абашидзе A.X. Защита прав меньшинств по международному и внутригосударственному праву. - М.: Права человека, 1996. - С.422.
} 
Подводя итог анализу различных определений термина «коренной народ» можно сделать следующий вывод: в международном праве до сих пор нет четкого и, главное, общепризнанного понятия данного термина. В то же время сложились некоторые характерные для коренных народов признаки, вытекающие из документов Международной организации труда, Всемирного банка и рабочего определения, сформулированного Специальным докладчиком по проблеме дискриминации коренного населения для Подкомиссии ООН по предупреждению дискриминации и защите меньшинств Хосе Мартинесом Кобо.

Во-первых, самый главный признак, который везде присутствует и не вызывает сомнений - это историческая связь (преемственность) коренных народов с территорией их настоящего проживания. То есть это привязка к определенной территории и людям, населявшим данную территорию ранее.

Во-вторых, это самосознание себя в качестве таковых. То есть коренные народы сознательно указывают на свою принадлежность к коренным народам и считают себя отличными от остальной части населения.

В-третьих, это наличие собственного языка, культуры, обычаев, традиций и иных социальных, экономических и политических институтов, полностью или частично регулирующих их жизнь.

И, последнее, это желание сохранить свою землю и этническую самобытность в качестве основы для продолжения своего существования как народа.

При этом факт покорения, колонизации, завоевания или захвата территорий коренных народов представителями иных народов, о котором упоминается в качестве необходимого признака в Конвенции МОТ № 169 и рабочем определении Хосе Мартинеса Кобо не является, на наш взгляд, определяющим признаком, а служит лишь основанием для выделения отдельной группы коренных народов, подвергнувшихся истреблению и захвату их территорий.

То же самое относится и к коренным народам, занимающимся охотой, рыболовством, собирательством и находящимся в прямой зависимости от окружающей природной среды, или от ареала их обитания и природных ресурсов, как говорится в документах Всемирного банка. Этот признак нельзя рассматривать как определяющий коренные народы в общем, однако, он позволяет нам также выделить отдельную категорию в числе коренных народов и направить усилия государств на защиту окружающей среды.

Таким образом, понятие «коренной народ» является слишком широким, и назрела необходимость вычленить из него несколько разновидностей коренных народов. Что касается определения «коренного населения» в Конвенции МОТ № 107, оно, на наш взгляд, не отвечает характеру современного международного права, так как носит дискриминационный характер и, соответственно, не должно приниматься во внимание при попытке дать определение понятию «коренной народ». Во внутреннем же законодательстве различных государств, при определении коренных народов, акцент, как правило, делается на национальной принадлежности индивидов к определенным народам или племенам, признанным правительством того или иного государства.

\section{Библиография:}

1. Bradford W. Morse. Participatory in Public and Aboriginal Governments in Northen Canada // Актуальные вопросы прав народов в современном мире. Материалы международной научнопрактической конференции / Отв. ред. Гарипов Р.Ш. - Казань: Издательство Татарского государственного гуманитарно-педагогического университета, 2009.

2. Hannum H. Autonomy Sovereignty and Self-determination. - Philadelphia, 1990.

3. James Crawford. The Rights of Peoples. - Oxford: Clarendon Press, 1988.

4. James S. Anaya. Indigenous Peoples in International Law. Second Edition. - Oxford University Press, 2004.

5. John R. Bowen. Should We Have a Universal Concept of «Indigenous Peoples' Rights»?: Ethnicity and Essentialism in the Twenty-First Century // Anthropology Today. - Vol. 16. - № 4. - 2000.

6. Lee Swepston. Indigenous and Tribal Peoples and International Law: Recent Developments // Current Anthropology. - Vol. 30. - № 2. - 1989. 
7. Thornberry P. International Law and the Rights of Minorities. - Oxford, 1991.

8. Абашидзе А.Х. Защита прав меньшинств по международному и внутригосударственному праву. - М.: Права человека, 1996.

9. Абашидзе А.Х., Ананидзе Ф.Р. Правовой статус меньшинств и коренных народов: международноправовой анализ. Монография. - М.: Издательство РУДН, 1997.

10. Ананидзе Ф.Р. Международно-правовые проблемы защиты прав коренных народов. - Дисс. ... на соискание ученой степени канд. юрид. наук. - Москва. - 1996.

11. Андреев К.Ю. Правовой статус коренных малочисленных народов в зарубежных странах. Справочник. - М.: РАН ИНИОН, 2006.

12. Блищенко И., Абашидзе А.Х. Коренные народы и международное право // Российская юстиция. - № 3. -1994.

13. Васильева Л.Н. Регулирование прав национальных меньшинств и коренных малочисленных народов: опыт Российской Федерации // Журнал российского права. - № 6. - 2005.

14. Даль В. И. Толковый словарь живого великорусского языка. - М., 1994. - Т.4.

15. История политических и правовых учений / Под. Ред. проф. Нерсесянца В.С. - М.: Норма, 2001.

16. Коренное население: глобальное стремление к справедливости. Доклад для Независимой комиссии по международным гуманитарным вопросам. - М., 1990.

17. Коренные народы Канады, нефть и закон: Сборник законодательных актов территории Юкон / Под ред. Солдаткина Е.И. и др. - М.: Ассоциация коренных малочисленных народов Севера, Сибири и Дальнего Востока Российской Федерации, 2002.

18. Кряжков В.А. Право на родной язык: на примере малочисленных народов Севера // Российский юридический журнал. - 2007. - № 1 .

19. Ли Свепстон. Конвенция Международной организации труда «О коренных народах и народах, ведущих племенной образ жизни, в независимых странах»: международный опыт ратификации и применения, проблемы и перспективы // Материалы Круглого Стола «О ратификации Российской Федерацией Конвенции МОТ № 169 «О коренных народах и народах, ведущих племенной образ жизни, в независимых странах». - М.: Общественная палата, 2006.

20. Международное публичное право. Курс лекций. / Отв. ред. проф. Курдюков Г.И. - Казань: Издательство «Центр инновационных технологий», 2004.

21. Международный пакт о гражданских и политических правах 1966 года // Международные акты о правах человека. Сборник документов. Издание второе, дополненное / Сост. Карташкин В.А., Лукашева Е.А. - М.: НОРМА.- 2002.

22. Морс Б. Сравнительная оценка положения коренных народов в Канаде, США, Австралии и Новой Зеландии // Человек и право: Книга о Летней школе по юридической антропологии. - М.: Стратегия, 1999.

23. МОТ - конвенции и рекомендации, принятые Международной конференцией труда, 1919-1966. Женева: Международное Бюро Труда, 1983.

24. Новикова Н.И. Права человека и права коренных народов Севера России // Человек и право. - М., 1999.

25. Организация Объединенных Наций, документ E/CN.4/Sub.2/1986/7 add.4, пункт 379.

26. Организация Объединенных Наций, документ E/CN.4/Sub.2/L/566 от 29 июня 1972 года.

27. Пешперова И.Ю. Гарантии прав коренных малочисленных народов с международном и внутригосударственном праве // Права коренных народов Севера: реализация международноправовых стандартов в Российской Федерации: Сборник научных статей / Под ред. акад. РАО Г.А. Бордовского, проф. С.А. Гончарова. - СПб.: Издательство РГПУ им. А.И. Герцена, 2005.

28. Пешперова И.Ю. Международно-правовая регламентация прав коренных народов // Правоведение. - № 1. -1998 .

29. Постановление Правительства РФ от 24.04.2000 года № 255 «О Едином перечне коренных малочисленных народов Российской Федерации» 
30. Права человека и народов. Учебное пособие / Под ред. проф. Миронова О.О. - Москва-Саратов: Издат. Центр ИНСР; Саратовский юридический институт МВД России. -2006.

31. Пунжин С.М. Проблема защиты прав меньшинств в международном праве // Государство и право. - № 8. -1992.

32. Соколовский С.В. Категория «коренные народы» в российской политике, законодательстве и науке // Kennan Occasional Papers. - Washington, 1999.

33. Ткаченко А.А., Корюхина А.В. К проблеме ратификации Российской Федерацией Конвенции МОТ № 169 «О коренных народах и народах, ведущих племенной образ жизни в независимых странах». // Этнографическое обозрение. - № 3. - 1995.

34. Тэпс Д. Соотношение понятий национальных меньшинств и коренных малочисленных народов // История государства и права. - 2006. - № 1.

35. Федеральный закон от 30.04.1999 года № 82-Ф3 «О гарантиях прав коренных малочисленных народов Российской Федерации» // СЗ РФ. - 1999. - № 18. - Ст.2208.

\section{References (transliteration):}

1. Bradford W. Morse. Participatory in Public and Aboriginal Governments in Northen Canada // Aktual'nye voprosy prav narodov v sovremennom mire. Materialy mezhdunarodnoi nauchno-prakticheskoi konferentsii / Otv. red. Garipov R.Sh. - Kazan': Izdatel'stvo Tatarskogo gosudarstvennogo gumanitarnopedagogicheskogo universiteta, 2009.

2. Hannum H. Autonomy Sovereignty and Self-determination. - Philadelphia, 1990.

3. James Crawford. The Rights of Peoples. - Oxford: Clarendon Press, 1988.

4. James S. Anaya. Indigenous Peoples in International Law. Second Edition. - Oxford University Press, 2004.

5. John R. Bowen. Should We Have a Universal Concept of «Indigenous Peoples’ Rights»?: Ethnicity and Essentialism in the Twenty-First Century // Anthropology Today. - Vol. 16. - № 4. - 2000.

6. Lee Swepston. Indigenous and Tribal Peoples and International Law: Recent Developments // Current Anthropology. - Vol. 30. - № 2. - 1989.

7. Thornberry P. International Law and the Rights of Minorities. - Oxford, 1991.

8. Abashidze A.Kh. Zashchita prav men'shinstv po mezhdunarodnomu i vnutrigosudarstvennomu pravu. - M.: Prava cheloveka, 1996.

9. Abashidze A.Kh., Ananidze F.R. Pravovoi status men'shinstv i korennykh narodov: mezhdunarodnopravovoi analiz. Monografiya. - M.: Izdatel'stvo RUDN, 1997.

10. Ananidze F.R. Mezhdunarodno-pravovye problemy zashchity prav korennykh narodov. - Diss. ... na soiskanie uchenoi stepeni kand. yurid. nauk. - Moskva. - 1996.

11. Andreev K.Yu. Pravovoi status korennykh malochislennykh narodov v zarubezhnykh stranakh. Spravochnik. - M.: RAN INION, 2006.

12. Blishchenko I., Abashidze A.Kh. Korennye narody i mezhdunarodnoe pravo // Rossiiskaya yustitsiya. - № 3. -1994.

13. Vasil'eva L.N. Regulirovanie prav natsional'nykh men'shinstv i korennykh malochislennykh narodov: opyt Rossiiskoi Federatsii // Zhurnal rossiiskogo prava. - № 6. - 2005.

14. Dal' V. I. Tolkovyi slovar' zhivogo velikorusskogo yazyka. - M., 1994. - T.4.

15. Kryazhkov V.A. Pravo na rodnoi yazyk: na primere malochislennykh narodov Severa // Rossiiskii yuridicheskii zhurnal. - 2007. - № 1.

16. Li Svepston. Konventsiya Mezhdunarodnoi organizatsii truda «O korennykh narodakh i narodakh, vedushchikh plemennoi obraz zhizni, v nezavisimykh stranakh»: mezhdunarodnyi opyt ratifikatsii i primeneniya, problemy i perspektivy // Materialy Kruglogo Stola «O ratifikatsii Rossiiskoi Federatsiei 
Konventsii MOT № 169 «O korennykh narodakh i narodakh, vedushchikh plemennoi obraz zhizni, v nezavisimykh stranakh». - M.: Obshchestvennaya palata, 2006.

17. Mors B. Sravnitel'naya otsenka polozheniya korennykh narodov v Kanade, SShA, Avstralii i Novoi Zelandii // Chelovek i pravo: Kniga o Letnei shkole po yuridicheskoi antropologii. - M.: Strategiya, 1999.

18. Novikova N.I. Prava cheloveka i prava korennykh narodov Severa Rossii // Chelovek i pravo. - M., 1999.

19. Peshperova I.Yu. Garantii prav korennykh malochislennykh narodov s mezhdunarodnom i vnutrigosudarstvennom prave // Prava korennykh narodov Severa: realizatsiya mezhdunarodno-pravovykh standartov v Rossiiskoi Federatsii: Sbornik nauchnykh statei / Pod red. akad. RAO G.A. Bordovskogo, prof. S.A. Goncharova. - SPb.: Izdatel'stvo RGPU im. A.I. Gertsena, 2005.

20. Peshperova I.Yu. Mezhdunarodno-pravovaya reglamentatsiya prav korennykh narodov // Pravovedenie. - № 1. - 1998.

21. Punzhin S.M. Problema zashchity prav men'shinstv v mezhdunarodnom prave // Gosudarstvo i pravo. - № 8. - 1992.

22. Sokolovskii S.V. Kategoriya «korennye narody» v rossiiskoi politike, zakonodatel'stve i nauke // Kennan Occasional Papers. - Washington, 1999.

23. Tkachenko A.A., Koryukhina A.V. K probleme ratifikatsii Rossiiskoi Federatsiei Konventsii MOT № 169 «O korennykh narodakh i narodakh, vedushchikh plemennoi obraz zhizni v nezavisimykh stranakh». // Etnograficheskoe obozrenie. - № 3. - 1995.

24. Teps D. Sootnoshenie ponyatii natsional'nykh men'shinstv i korennykh malochislennykh narodov // Istoriya gosudarstva i prava. - 2006. - № 1 . 